\title{
Studies on Pruning Cuts and Wound Dressings for Oak Wilt Control
}

\author{
Kim Camilli, David N. Appel, and W. Todd Watson
}

\begin{abstract}
Ceratocystis fagacearum causes the destructive tree disease called oak wilt. One means of pathogen spread is by insect vectors (Nitidulidae) that transmit spores into fresh wounds on healthy trees. Experiments were conducted in central Texas on native live oaks (Quercus fusiformis) to test pruning methods and paints on disease development. Three treatment combinations were tested on 30 trees (10 trees/treatment): flush cut unpainted, flush cut painted, and unpainted pruning cuts made according to the Shigo method. Unpainted puncture wounds were made on the lower trunks of an additional 20 trees as controls. C. fagacearum spores were applied to the pruning cuts and half of the puncture wounds (positive controls) after treatment, whereas the other half of the punctures received distilled water as negative controls. Oak wilt symptoms first appeared in the flush cut unpainted treatment 31 days after inoculation. Infection rates, in decreasing order, were; positive control (70\%), flush cut unpainted (60\%), Shigo pruning method (40\%), flush cut painted (20\%), and negative control $(10 \%)$. Pruning wounds, regardless of method, were effective infection courts for the oak wilt pathogen. Fewer trees became infected when pruning cuts were painted, but differences among infection rates for pruning cuts were not statistically significant. Tree diameters and stem aspect ratio had no bearing on infection rates. The Shigo method is recognized as a superior method for pruning, but there is no reason to change current recommendations to paint fresh wounds on susceptible oaks in high-hazard oak wilt areas.
\end{abstract}

Key Words. Branch protection zone; natural target pruning; nitidulid beetles; oak wilt; pruning paints; Shigo.

Ceratocystis fagacearum (Bretz) Hunt, the pathogen responsible for the highly destructive oak wilt disease, spreads in two ways (Gibbs and French 1980; MacDonald and Hindal 1981). Over relatively short distances, spores of the fungus are drawn from diseased to healthy trees through root connections. These connections arise from grafting or from common root systems formed during vegetative propagation by root sprouts. Because root connections play an important role in oak mortality in Texas, U.S., considerable resources are expended on control in live oak (Quercus fusiformis Small) to prevent root transmission of the pathogen (Appel 2001). The second means of spread for $C$. fagacearum is over longer distances by sap-feeding beetles (Coleoptera: Nitidulidae). Inoculum sources called fungal mats form on diseased red oaks (gen. Quercus sub gen. Erythrobalanus) and provide spores for nitidulid beetles to spread to fresh wounds on healthy oaks (Norris 1953; Curl 1955; Jewell 1955; Rexrode 1976; Juzwik et al. 1985; Appel et al. 1987, 1990; Ambourn et al. 2005). From an epidemiologic perspective, the initiation of new disease centers by nititulids is a critical stage in the oak wilt disease cycle. This means of spread is also a controversial issue for arborists throughout the range of oak wilt because pruning wounds are implicated as important infec- tion courts for nitidulids in the oak wilt syndrome. Much of the controversy involves the recommended oak wilt control measure of applying wound dressings to prevent nitidulids from inoculating pruning cuts on susceptible trees.

Many other studies have also shown that wound dressings have some benefits when used to prevent infection from the fungal spores of various pathogens (May and Palmer 1959; Luepschen and Rohrbach 1969; Gupta and Agarwala 1972; Davis and Peterson 1973; Mercer 1982; Juzwik et al. 1985; Biggs 1990). Luepschen and Rohrbach (1969) demonstrated that wound susceptibility of Prunus spp. to Leucostoma spp., the pathogen causing a perennial canker disease of stone fruits, varied by time of year and that the application of shellac was beneficial in reducing infection. Similar benefits of pruning paints to control infection of Malus spp. with Cylindrocarpon mali, another canker disease of apples, have also been demonstrated (Gupta and Agarwala 1972). Not all studies, however, regarding wound dressings and their effect on disease control have been conclusive. Biggs (1990) found that wound susceptibility to infection decreases with increasing suberin and lignin formation after wounding. This varies considerably based on temperature, soil moisture, and species. After testing the effects of several postwounding treat- 
ments, Biggs (1990) demonstrated that wound dressings, depending on type, can either hasten or retard suberin and lignin formation and infection by Leucostoma spp. in wounded Prunus spp. A number of wound dressings have been shown to inhibit the growth of Ceratocystis fimbriata f. platani (May and Palmer 1959; David and Peterson 1973).

In contrast to any benefits, several studies have also shown that wound dressings can be phytotoxic or nonbeneficial to trees (Neely 1970; Wilson and Shigo 1973; Shigo and Wilson 1977; Mercer 1979; Shigo and Shortle 1983; Hudler and Jensen-Tracy 2002). These studies were directed toward the use of wound dressings to prevent the ingress of decay fungi in trees. Neely (1970) showed that petrolatum, latex paint, shellac, and asphalt compounds do not promote wound closure. Shigo and Shortle (1983) tested several wound treatments in long-term experiments. They found that the treatments did not inhibit wood discoloration and that some wound dressings could harm trees. As a result, Shigo and Shortle (1983) strongly recommended that arborists discontinue the use of wound dressings.

As a result of the requirement of fresh wounds for infection by the oak wilt pathogen, wound treatments have long been a potential control measure of interest to researchers and practitioners (Drake et al. 1958; Gibbs 1980). Juzwik et al. (1985) wounded over 5,000 trees to study natural infection of oaks with C. fagacearum. In Minnesota, infection from wounding occurred from May to mid-June. Numerous wounds were treated with a variety of commercially available wound dressings including Leonard's Tree Compound (A.M. Leonard and Sons, Inc., Piqua, OH), Cabots Tree Healing Paint (Samuel Cabot Mfg., Inc., Boston, MA), and Treekote (Walter C. Clark and Son, Orange, CT). Of the 322 wounded trees treated with wound dressings, none of the trees became infected nor did any unwounded trees contract the disease. Infection rates on untreated trees in different plots varied from $3 \%$ to $29 \%$ depending on location and time of year the tree was wounded. As a result of these and other related studies, most educational materials developed by state and federal agencies include wound paints as part of comprehensive oak wilt control programs (Appel et al. 1995; French and Juzwik 1999; O'Brien et al. 2000; Bonello 2001; CummingsCarlson and Martin 2005).

Wound closure has also been implicated as important to the status of oak wilt infection courts. Rates of closure have been found to be associated with how pruning cuts are made in relation to branch collars and branch attachments (Shigo 1984, 1985). In this model, branches stay separate from the parent stem from which they arise. As branches and stems increase in girth, a branch bark ridge forms at the top of the junction of the branch and stem. Many times, there will be a swollen ring of tissue at the bottom of the branch, indicating the branch collar. Proper pruning cuts are those that involve cutting outside the branch bark ridge and as close to the branch collar as possible without damaging the branch collar (Shigo 1984). In addition, branches have branch protection zones (BPZ) that limit infection in the parent stem after branch injury or removal by forming pathogen-resistant compounds within the branch tissue (Von Aufess 1975, 1984; Green et al. 1981; Shigo 1985). Improper, or flush, cuts damage the tissue of the parent stem and therefore bypass the inherent physical and chemical barriers present in the branch. Several studies have demonstrated that pruning cuts through branch collars result in increased discoloration in the parent stem outside of the branch tissue (Neely 1970; Solomon and Shigo 1976; Shigo 1984, 1985; Eisner et al. 2002a). These studies have convinced many arborists to abandon the use of pruning paints when pruning oaks in areas infested with oak wilt in favor of relying on the anatomic advantages of a proper pruning cut.

An important point to note is that these studies of wound closure involve branches. Not all stem attachments comprise true branches with BPZs and branch collars. True branches, as opposed to codominant stems, can be difficult to define. Eisner et al. (2002a) looked at three different criteria to determine how well branches compartmentalize discoloration associated with pruning cuts on live oaks (C. virginiana). These were visible collars, pith connections between the branch and parent stems, and the aspect ratio (branch diameter to trunk diameter). Their research found that branches with visible branch collars had significantly less discolored wood after pruning. There was significantly less discoloration in pruning cuts where the piths of the branch and the parent stem did not connect. These morphologic features and their influence on discoloration support findings by Shigo (1985). Most branches (89\%) with visible branch collars did not have connected piths. The extent of discoloration increased as aspect ratios increased to 1 (codominant stems). In addition, branches with lower aspect ratios had fewer pith connections. Pruning branches with aspect ratios lower than the predicted ratio (0.39) resulted in relatively small amounts of discolored wood. In a related study, Eisner et al. (2002b) demonstrated that branches with lower aspect ratios, no pith connections, and visible branch collars had lower conductivity ratios, which means that these features are associated with restricted movement of water from the parent stem to the branch. They found that lower conductivity ratios result in a decrease in discoloration, and this restriction in water flow may also reduce the infection potential of C. fagacearum. Studies measuring the impact of proper pruning to limit disease transmission must ensure that true branches, rather than codominant stems that do not have branch collars or BPZs, are used to accurately assess the benefits of these inherent morphologic features.

To address these concerns, a study was developed to determine the accuracy of current recommendations for applying pruning paints to pruning wounds on susceptible live oaks 
as a precaution against vector transmission of $C$. fagacearum. The objectives of this study were (1) to determine if pruning paint served as an effective sealant to protect flush cuts from infection, and (2) to determine if the physical and chemical barriers present in proper pruning cuts on branches without pruning paint were sufficient to limit infection.

\section{MATERIALS AND METHODS}

The study was conducted on an oak-woodland ranch north of Austin, Texas, located at $-97^{\circ} 45^{\prime} 12^{\prime \prime} \mathrm{W}$ and $30^{\circ} 28^{\prime} 23^{\prime \prime} \mathrm{N}$. The tree species on the ranch consisted mainly of live oaks $(Q$. fusiformis), but cedar elm (Ulmus crassifolia) and gum bumelia (Bumelia lanuginose) were also present. This site was selected as a result of the high concentration of susceptible live oaks and the presence of oak wilt in the immediate vicinity, precluding the introduction of the disease into a new area. There were also no red oaks in the study site, so overland transmission of the fungus by vectors from other oak wilt centers was unlikely. The 12 week study was conducted from 30 April 2003 to 21 July 2003 during a period of high susceptibility for oak wilt (Appel et al. 1987).

Live oaks were selected with trunk diameters ranging from 10 to $44.5 \mathrm{~cm}$ (4 to $17.8 \mathrm{in}$ ) diameter breast height. A total of five treatments were implemented. Each treatment consisted of 10 trees for a total of 50 trees. The treatments consisted of: (I) puncture wound-positive control, (II) puncture woundnegative control, (III) flush pruning cut unpainted, (IV) flush pruning cut painted with pruning paint, and $(\mathrm{V})$ proper pruning cut unpainted as described by Shigo (1984) (Figure 1). Measurements of all branch diameters and the vertical faces of the pruning cuts were all made before treatment. Branches used in treatment III, IV, and V had visible branch collars. Healthy trees with stem aspect ratios (branch diameter to parent stem diameter) ranging from 0.27 to 0.52 were used for the pruning treatments as defined by Eisner et al. (2002a). The pruning cuts were made by an International Society of Arboriculture ISA-Certified Arborist and pictures documenting each pruning cut were taken. The tree wound dressing TreeKote Aerosol (Walter C. Clark and Son) was used to seal the 10 flush pruning cuts for treatment IV. The positive and negative control treatments (I and II) entailed wounding the tree using a disinfected screwdriver hammered into the base of the tree and pulled back to expose the vascular system. For treatments III and IV, the branch collar was cut flush to the parent limb. In treatment $\mathrm{V}$, the branch collar and the branch bark ridge were not cut.

The spore suspensions used in treatments I, III, IV, and V were prepared by using a fresh isolate of $C$. fagacearum that was obtained from a nearby disease center in March 2003. The sample was taken from a live oak exhibiting typical oak wilt symptoms. A bole sample containing vascular xylem tissue was removed from the tree, placed on ice, and returned to the laboratory for processing. The sample chips were sur-

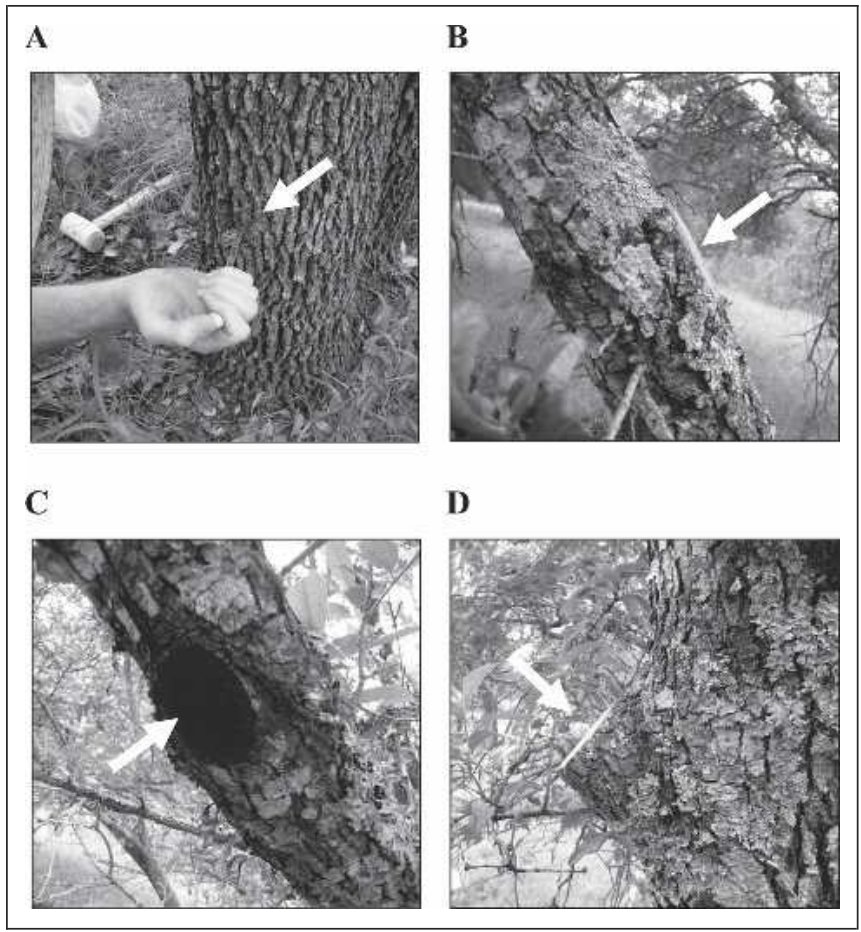

Figure 1. Treatment types for inoculation of Quercus fusiformis with Ceratocystis fagacearum. (A) Positive and negative (treatments I and II); (B) flush pruning cut, unpainted (treatment III); (C) flush pruning cut, painted (treatment IV); and (D) proper pruning cut (treatment V). Arrows indicate location of wounds.

face sterilized in $10 \%$ hypochlorite for $1 \mathrm{~min}$ and plated onto Petri plates with potato dextrose agar acidified with $0.1 \%$ hydrochloride. The resulting $C$. fagacearum isolate was separated in pure culture to be used for the inoculation treatments. A spore suspension of $2.9 \times 10^{6}$ conidia/mL was made on 29 April 2003 and stored in a refrigerator until inoculation.

Inoculation of the treatments I, III, IV, and V were made with a few drops of the fresh spore suspension of $2.9 \times 10^{6}$ spores $/ \mathrm{mL}$ on 30 April 2003. Inoculations were made early in the spring, before temperatures became too hot. High temperatures are known to limit $C$. fagacearum growth. Sterilized distilled water was used on the negative control (treatment II). The spore suspension was applied with a dropper to the basal wound for treatment I. Treatments III and V were inoculated 10 min after the pruning cut was made. The spore solution was brushed onto the cut surface with a sterilized paintbrush. For treatment IV, the wound was immediately sprayed with the tree wound dressing and then allowed to dry for $30 \mathrm{~min}$. The entire pruning cut was coated with the tree wound dressing. Once the tree wound dressing was dry to touch, the wound was then inoculated with the spore suspension by using a sterile paintbrush.

Live oaks grow in groups, termed motts, consisting of highly interconnected trees growing on common root systems 
and grafted roots. This growth habit complicated tree selection because the pathogen could rapidly move through the connections among treated trees and obscure the results of the treatments. The experimental design was also planned with the intention of confining the property damage to a minimal area. These conditions resulted in a limited number of available trees that had adequate aspect ratios and tree spacing, making placement of the treatments critical. To compensate, a buffer tree was left between the treated trees to limit movement of the fungus through root grafts into an adjacent treated tree within the same mott during the experimental period. All 50 trees were checked for symptom development every 7 days for 10 weeks.

The five treatments were tested for significance by using the general linear model in SAS (SAS, Cary, NC) as well as the Calculation for the Chi-Square Test, an interactive calculation tool for $\chi^{2}$ tests of goodness of fit and independence (Preacher 2005). Each pair of treatments was tested using the $\chi^{2}$ calculator as well. Single-factor analysis of variance using MS Excel poptools (Hood 2003) was used to determine significant differences in trunk diameters, aspect ratios, areas of exposed pruning cuts, and the time of day when the inoculation was accomplished.

\section{RESULTS}

Initial symptoms in some treatments were observed 31 days after inoculation (Figure 2). After 12 weeks, some trees became infected in each of the treatments. During the course of the experiment, typical diagnostic oak wilt symptoms were regularly observed (Appel et al. 1995). Forty days after inoculation, veinal necrosis began to appear and tip burn of the leaves was visible. The development of symptom expression on infected trees progressed from brown leaves to tip burn to vein banding and veinal necrosis that eventually encompassed the entire crown resulting in crown loss.

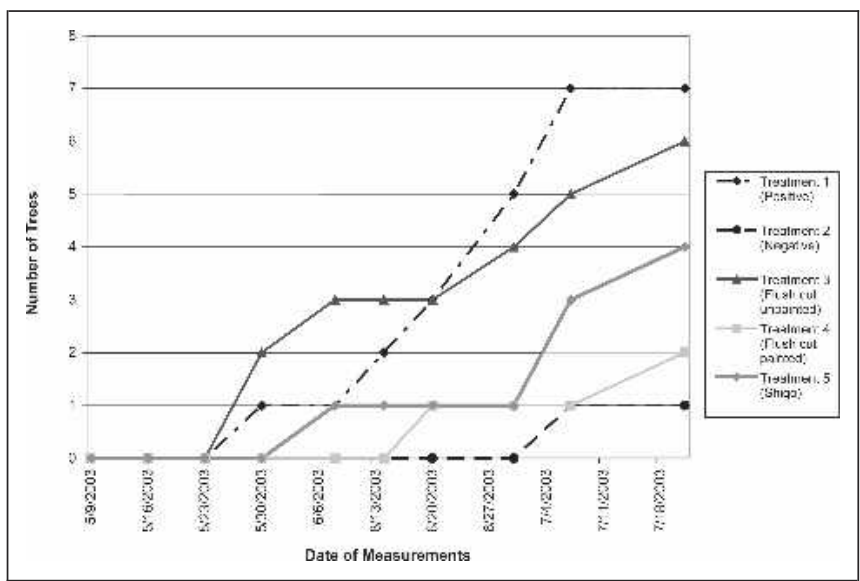

Figure 2. Symptom expression of Quercus fusiformis after inoculation with Ceratocystis fagacearum on 30 April 2003.
At the end of the 12 week study period, significant differences were found between the positive and negative control treatments $(P=0.006)$. The positive control group (treatment I) exhibited the greatest number of infected trees $(70 \%)$ (Table 1, Figure 2). The least number of infected trees after 12 weeks was in the negative controls (treatment II) in which one tree $(10 \%)$ became symptomatic. This was likely the result of the fungus spreading from a nearby infected treated tree to the negative control tree and resulted in termination of the experiment. The buffer tree between the two treatments was infected as well. The flush cut unpainted wounds (treatment III) had the next highest infection level $(60 \%)$ and were also significantly greater than the negative control treatments $(P=0.019)$. Painting the flush cuts (treatment IV) reduced the infection level to $20 \%$, which made that treatment significantly less than the positive controls $(P=0.024)$. On one of these trees that became infected, the paint was not completely dry and slipped off the wound, partially exposing the cut surface of the branch, when the spore inoculation was brushed onto the wound. This tree was immediately resprayed with pruning paint and allowed to dry before reapplication. Of the trees that were treated with the Shigo cuts (treatment V), 40\% became infected as shown in Table 1. There were no significance differences among the nonflush cut treatments and the other treatments.

Using single-factor analysis of variance, there were no significant differences $(P=0.6093)$ among mean trunk diameters (diameter breast height) for the five treatments (Table 2). When testing the flush cut painted, flush cut unpainted, and proper pruning cut treatments, there were no significant differences among stem aspect ratios (Table 3). Although more trees became infected with stem ratios of 0.3 to 0.39 and 0.4 to 0.49 , there were no significant differences in percentages of infection among branch-stem ratios $(P=0.2578)$. As seen in other studies, flush cut branches resulted in larger wounds than proper pruning cuts outside the branch collar (Herring et al. 1958; Neely 1970). There were significant differences between the flush cuts that were not painted and

Table 1. Numbers of trees infected with $C$. fagacearum per treatment type.

\begin{tabular}{|c|c|c|c|c|}
\hline Treatments (no.) & Diseased $^{\mathrm{z}}$ & Healthy & Total & $\begin{array}{l}P \text { value } \\
\text { (comparison) }\end{array}$ \\
\hline Positive control (I) & $7 \mathrm{a}$ & 3 & 10 & $0.006(\mathrm{I}, \mathrm{II})$ \\
\hline Flush cut unpainted & $6 \mathrm{ab}$ & 4 & 10 & 0019 (II III) \\
\hline Shigo cut (V) & $4 \mathrm{abc}$ & 6 & 10 & \\
\hline $\begin{array}{l}\text { Flush cut painted } \\
\text { (IV) }\end{array}$ & $2 \mathrm{bc}$ & 8 & 10 & 0.024 (I, IV) \\
\hline Negative control (II) & $1 \mathrm{c}$ & 9 & 10 & \\
\hline
\end{tabular}

${ }^{\mathrm{z}}$ Numbers in column followed by the same letter are not statistically different as determined with

$\chi^{2}$ goodness of fit at $P \leq 0.05$. 
Table 2. Mean diameters at breast height (dbh) of trees within treatments ${ }^{2}$.

\begin{tabular}{lll}
\hline Treatments (no.) & $\begin{array}{l}\text { Mean diameter } \\
\text { breast height }(\mathrm{cm})\end{array}$ & $\begin{array}{l}\text { Standard } \\
\text { error }\end{array}$ \\
\hline Positive control (I) & 17.89 & 0.4792 \\
Negative control (II) & 17.52 & 0.8942 \\
Flush cut painted (IV) & 20.70 & 1.1187 \\
Flush cut unpainted (III) & 20.06 & 1.0136 \\
Shigo cut (V) & 22.26 & 1.0804 \\
\hline
\end{tabular}

${ }^{\mathrm{z}}$ Diameter Breast Height among treatments were not significant at $P=$ 0.6093 .

the Shigo cuts $(P=0.10)$ (Table 4$)$. In addition, although the maximum air temperature reached $28^{\circ} \mathrm{C}\left(82.5^{\circ} \mathrm{F}\right)$ (Texas Commission on Environmental Quality 2003) during the day that the trees were inoculated, there were no significant differences in infection as a result of time of inoculation throughout the day (results not shown).

\section{DISCUSSION}

Some clear conclusions can be drawn from the results of these inoculation studies. Pruning cuts are effective infection courts for the oak wilt pathogen. Whether they are flush cuts or properly made according to the nonflush cut method, $C$. fagacearum is able to infect the wound and colonize the tree. There is some evidence that the Shigo cut may have some benefit in reducing infections, but the statistical significance is not sufficiently conclusive. Pruning paints provided greater protection, but again, the differences were not statistically significant. Although neither of the measures was 100\% effective in preventing infection by $C$. fagacearum, both may be useful to protect against vector-borne transmission of the oak wilt fungus. As expected, the average sizes of flush cut pruning wounds were larger than those pruning cuts made by the Shigo method. Previous research studies illustrated that flush cut branches resulted in larger wounds then when cuts were properly made outside the branch (Herring et al. 1958; Neely 1970). In addition to the damage to the branch collar from a flush cut, the larger wound may increase the likelihood of infection as a result of the greater surface area.

The results of the studies need to be interpreted with an understanding of how the experimental application of spores might compare with natural conditions. Presumably, contaminated nitidulid beetles are attracted to fresh wounds by volatile compounds released from the exposed cut, just as they are attracted to certain artificial baits and pheromones (Kyhl et al. 2002). On arrival at the wound site, spores would be mechanically deposited on the exposed vascular system in a manner similar to wiping with a contaminated paintbrush but at a lower concentration than that used in the artificial treatments. If wound paints are to be effective in preventing infection, they must either prevent the attractants, or volatiles, from successfully attracting the nitidulids, they must provide a barrier to prevent the nitidulid from depositing spores, or both. As mentioned previously, the paint slipped during the inoculation of one of the trees in treatment IV, which likely resulted in the infection of that tree. If this was the case, then the importance of using pruning paints to minimize infections related to pruning is even more critical.

Another important fact is that live oaks tend to abort their terminal buds and form codominant stems. Therefore, we found it very difficult to locate true branches within the canopies, which is why we had to use stem aspect ratios that were slightly higher than the predicted threshold ratio recommended by Eisner et al. (2002a). This observation concerning live oaks is critical. Even if proper pruning cuts were effective at limiting infection by $C$. fagacearum, pruning paints would still be required as a result of the high numbers of pruning cuts on stems without branch collars and BPZs. Therefore, the prudent approach for an arborist to maximize protection against infection is to make proper pruning cuts where possible and use pruning paints as an added barrier. Because vectors can theoretically infect open wounds soon after they are created, pruning paints should be applied immediately after each pruning cut.

Many of the questions left unanswered by the current study could be addressed by similar experiments with larger numbers of treated trees. Size of the pruning cut, time of year, and types of pruning paint are all important variables that should be tested. However, the opportunity to conduct inoculation experiments in Texas with the oak wilt pathogen is rare as a result of the potential for causing losses of large numbers of trees. Regardless of the limitations of the current study, we have no reason to warrant changing the current recommen-

Table 3. Distribution of infected/treated trees by treatment and stem aspect ratios on 21 July $2003^{z}$.

\begin{tabular}{|c|c|c|c|c|c|c|}
\hline \multirow[b]{2}{*}{ Treatments (no.) } & \multicolumn{4}{|c|}{ Stem aspect ratios } & \multirow[b]{2}{*}{ Mean } & \multirow[b]{2}{*}{ Standard error } \\
\hline & 0.2 to 0.29 & 0.3 to 0.39 & 0.4 to 0.49 & 0.5 to 0.59 & & \\
\hline Flush cut unpainted (III) & $1 / 1$ & $1 / 2$ & $3 / 6$ & $1 / 1$ & 0.3929 & 0.0214 \\
\hline Flush cut painted (IV) & $0 / 1$ & $0 / 4$ & $2 / 5$ & $0 / 0$ & 0.4246 & 0.2061 \\
\hline Shigo cut $(\mathrm{V})$ & $0 / 1$ & $3 / 5$ & $1 / 4$ & $0 / 0$ & 0.3749 & 0.1936 \\
\hline Total & $1 / 3$ & $4 / 11$ & $6 / 15$ & $1 / 1$ & & \\
\hline
\end{tabular}

${ }^{\mathrm{z}}$ Numbers of infected trees among stem aspect ratios was not statistically significant $(P=0.2578)$. 
Table 4. Diameters of pruning wound surfaces for the three pruning treatments ${ }^{z}$.

\begin{tabular}{llll}
\hline Treatments (no.) & Range & $\begin{array}{l}\text { Mean wound } \\
\text { diameter (cm) }\end{array}$ & $\begin{array}{l}\text { Standard } \\
\text { error }\end{array}$ \\
\hline Flush cut unpainted (III) & 4.1 to 17.0 & $7.8 \mathrm{a}$ & 1.3568 \\
Flush cut painted (IV) & 4.8 to 8.1 & $6.6 \mathrm{ab}$ & 0.3908 \\
Shigo cut (V) & 2.8 to 8.1 & $5.3 \mathrm{~b}$ & 0.5283 \\
\hline
\end{tabular}

${ }^{\mathrm{z}}$ Mean wound diameters followed by different letters are significantly different, $P=0.10$.

dations for oak wilt prevention in Texas. Intentional wounding of oaks in high-risk areas for infection by $C$. fagacearum should be limited to seasons when fungal mats are not forming and the nitidulid populations are minimal. In Texas, 1 February through 1 June are considered to be an undesirable times to prune trees, but, as a result of climatic variation, caution should be exercised during other periods as well. Pruning paints and proper pruning are considered to be important measures to further minimize the likelihood of an infection and promote tree health.

\section{IMPLICATIONS FOR ARBORICULTURE}

Controversy has existed for years in the arboriculture profession concerning the value of applying wound dressings to pruning cuts as an effective deterrent to the spread of Ceratocystic fagacearum. This study article discusses much of the research that has led to the current controversy and provides valuable new evidence supporting the need to apply pruning paints to all wounds on susceptible trees in areas with oak wilt.

Acknowledgments. The use of trade names in this publication does not imply endorsement by the authors or Texas A\&M University of the products named nor criticism of similar ones not mentioned. We acknowledge the technical assistance of the following Texas A\&M University collaborators: Mr. Thomas Kurdyla, technician, and Mr. Jeff Lehde, graduate student.

\section{LITERATURE CITED}

Ambourn, A.K., J. Juzwik, and R.D. Moon. 2005. Seasonal dispersal of the oak wilt fungus by Colopterus truncatus and Carpophilus sayi in Minnesota. Plant Disease 89: 1067-1076.

Appel, D.N. 2001. The basics of oak wilt biology and factors influencing disease incidence and severity, pp. 71-81. In Shad Tree Wilt Diseases. Ash, C.L., Ed. The American Phytopathological Society, St. Paul, MN. 257 pp.

Appel, D.N., R.S. Cameron, A.D. Wilson, and J.D. Johnson. 1995. How to identify and manage oak wilt in Texas. How-to SR-1 USDA Forest Service, Southern Research Station; New Orleans, LA. 7 pp.
Appel, D.N., T. Kurdyla, and R. Lewis. 1990. Nitidulids as vectors of the oak wilt fungus and other Ceratocystis spp. in Texas. European Journal of Forest Pathology 20: 412-417.

Appel, D.N., R. Peters, and R. Lewis. 1987. Tree susceptibility, inoculum availability, and potential vectors in a Texas oak wilt center. Journal of Arboriculture 13: 169-173.

Biggs, A.R. 1990. Managing wound-associated diseases by understanding wound healing in the bark of woody plants. Journal of Arboriculture 16:108-112.

Bonello, P. 2001. Oak wilt. Ohio State University Extension Factsheet HYG-3306-01. Ohio State University, Columbus, OH. 4 pp.

Cummings-Carlson, J., and A.J. Martin. 2005. Lake State Woodlands oak wilt management-what are the options? Publication No. G3590. University of Wisconsin Cooperative Extension, Madison, WI.

Curl, E.A. 1955. Natural availability of oak wilt inocula. Bulletin of the Illinois Natural History Survey 26: 277-323.

Davis, S.H. Jr., and J.L. Peterson. 1973. A tree wound dressing to prevent spread of the Ceratocystis causing canker stain of the planetree. Plant Disease Report 57:28-30.

Drake, C.R., J.E. Kuntz, and A.S. Riker. 1958. Tree Wounds and Long Distance Spread of Oak Wilt. Forest Research Note. Wisconsin College of Agriculture 39. 3 pp.

Eisner, N.J., E.F. Gilman, and J.C. Grabosky. 2002a. Branch morphology impacts compartmentalization of pruning wounds. Journal of Arboriculture 28:96-102.

Eisner, N.J., E.F. Gilman, J.C. Grabosky, and R.C. Beeson Jr. 2002b. Branch junction characteristics affect segmentation in red maple. Journal of Arboriculture 28:245-251.

French, D.W., and J. Juzwik. 1999 (revised). Oak wilt in Minnesota. Extension publication MI-3174-GO. Minnesota Extension Service, St. Paul, MN. 5 pp.

Gibbs, J.N. 1980. Role of Ceratocystis piceae in preventing infection by Ceratocystis fagacearum in Minnesota. Transactions of the British Mycological Society 74: 171-174.

Gibbs, J.N., and D.W. French. 1980. The Transmission of Oak Wilt. USDA Forest Service Research Paper, NC-185. $17 \mathrm{pp}$.

Green, D.J., W.C. Shortle, and A.L. Shigo. 1981. Compartmentalization of discolored and decayed wood in red maple branch stubs. Forest Science 27:519-522.

Gupta, G.K., and R.K. Agarwala. 1972. Effectivity of wound dressing in the control of apple tree canker (Cylindrocarpon mali). Indian Journal of Mycology and Plant Pathology 2:91-92.

Herring, H.G., V.J. Rudolph, and W.A. Lemmien. 1958. Wound area as influenced by closeness of pruning. Journal of Forestry 56:219-220. 
Hood, G.M. 2003. Poptools version 2.5.9. http:// www.cse.csiro.au/poptools (accessed 10/03/05).

Hudler, G.W., and S. Jensen-Tracy. 2002. Lac Balsam ${ }^{\circledR}$ as a treatment to hasten wound closure and minimize discoloration and decay. Journal of Arboriculture 28:264-269.

Jewell, F.F. 1955. Insect transmission of oak wilt. Phytopathology 46:244-257.

Juzwik, J., D.W. French, and J. Jeresek. 1985. Overland spread of the oak wilt fungus in Minnesota. Journal of Arboriculture 11:323-327.

Kyhl, J.F., R.J. Bartelt, A. Cossé, J. Juzwik, and S.J. Seybold. 2002. Semiochemical-mediated flight responses of sap beetle (Coleoptera: Nitidulidae) vectors of oak wilt, Ceratocystis fagacearum. Journal of Chemical Ecology 28: 1527-1547.

Luepschen, N.S., and K.G. Rohrbach. 1969. Cytospora canker of peach trees: Spore availability and wound susceptibility. Plant Disease Report 53:869-872.

MacDonald, W.L., and D.F. Hindal. 1981. Life cycle and epidemiology of Ceratocystis, pp. 113-144. In Fungal Wilt Disease in Plants. Mace, M.E., and Bell A.A., Eds. Academic Press, NY.

May, C., and J.G. Palmer. 1959. Effect of selected fungicideasphalt mixtures on the growth of Ceratocystis fimbriata F. plantani in vitro. Plant Disease Report 43:565-566.

Mercer, P.C. 1979. Phytotoxicity and fungitoxicity tests for tree wound paints. The Annals of Applied Biology 91: 199-202.

- 1982. Tree wounds and their treatment. Arboriculture Journal 6:131-137.

Neely, D. 1970. Healing of wounds on trees. Journal of the American Society for Horticultural Science 95:536-540.

Norris, D.N. 1953. Insect transmission of oak wilt in Iowa. Plant Disease Report 37:417-418.

O'Brien, J.G., M.E. Mielke, D. Starkey, and J. Juzwik. 2000. How to Identify, Prevent and Control Oak Wilt. NA-PR03-00. USDA Forest Service, Northeastern Area State and Private Forestry; St. Paul, MN.

Preacher, K.J. 2005. Calculation for the Chi-Square Test, An interactive calculation tool for chi-square tests of goodness of fit and independence. L.L. Thurstone Psychometric Laboratory, University of North Carolina at Chapel Hill. http://www.unc.edu/ preacher/chisq/chisq.htm (accessed 9/25/05).

Rexrode, C.O. 1976. Insect transmission of oak wilt. Journal of Arboriculture 2:61-66.

Shigo, A.L. 1984. Tree decay and pruning. Journal of Arboriculture 8:1-12.

1985. How tree branches are attached to trunks. Canadian Journal of Botany 63:1391-1401.

Shigo, A.L., and W.C. Shortle. 1977. New ideas in tree care. Journal of Arboriculture 3:1-6.
1983. Wound dressings: Results of studies over 13 years. Journal of Arboriculture 9:317-329.

Shigo, A.L., and C.L. Wilson. 1977. Wound dressings on red maple and American elm: Effectiveness after five years. Journal of Arboriculture 3:81-87.

Solomon, D.S., and A.L. Shigo. 1976. Discoloration and decay associated with pruning wounds on yellow birch. Forest Science 22:391-392.

Texas Commission on Environmental Quality. 2003. Outdoor temperature hourly averages. http://www.tceq.state.tx.us/ (accessed 11/17/05).

Von Aufess, H. 1975. The formation of a protective zone at the base of branches of broad-leaved and coniferous trees and its effectiveness in preventing fungi from penetrating into the heartwood of living trees. Forstwissenschaftliches Centralblatt 94:140-152.

- 1984. Some examples of wood discolorations related to mechanisms for potential protection of living trees against fungal attack. IAWA Bulletin 5:133-138.

Wilson, C.L., and A.L. Shigo. 1973. Dispelling myths in arboriculture today. American Nurseryman 137:24, 26, 28.

\section{Kim Camilli}

Staff Forester II

Texas Forest Service

Austin, TX 78761-5083, U.S.

David N. Appel

Professor

Department of Plant Pathology and Microbiology

Texas A\&M University

College Station, TX 77843-2132, U.S.

W. Todd Watson (corresponding author)

Assistant Professor of Urban and Community Forestry

Department of Forest Science

Texas A\&M University

College Station, TX 77843-2135, U.S.

t-watson@tamu.edu

Résumé. Ceratocystis fagacearum cause une maladie destructrice appelée la flétrissure verticilléenne du chêne. Une des manières que le pathogène est disséminé se fait via des insectes vecteurs (Nitidulidae) qui transmettent les spores dans des blessures fraîches faites sur des arbres en bonne santé. Des expériences ont été menées dans le Centre du Texas sur des chênes indigènes (Quercus fusiformis) pour tester les méthodes d'élagage et les produits de recouvrement par rapport au développement de la maladie. Trois combinaisons de traitement ont été testées sur 30 arbres (10 arbres par traitement), soient: coupe rase sans produit de recouvrement, coupe rase avec produit de recouvrement, coupe d'élagage sans produit de recouvrement et faite selon la méthode Shigo. Des blessures non recouvertes 
de produit ont aussi été faites sur la section inférieure du tronc de 20 arbres additionnels afin de constituer des groupes témoins. Des spores de Ceratocystis fagacearum ont été appliquées sur les coupes d'élagage ainsi que sur la moitié des blessures (groupe de contrôle positif) après le traitement tandis que l'autre moitié des blessures ont reçu de l'eau distillée en tant que groupe contrôle négatif de la maladie. Les symptômes de la flétrissure verticilléenne sont apparus en premier sur les coupes rases non recouvertes de produit 31 jours après le traitement d'inoculation. Les taux d'infection, dans un ordre décroissant, ont été: contrôle positif (70\%), coupe rase sans produit de recouvrement (60\%), coupe selon la méthode Shigo (40\%), coupe rase avec produit de recouvrement $(20 \%)$ et contrôle négatif (10\%). Les blessures d'élagage, peu importe la méthode, constituent des milieux favorables à la flétrissure verticiléenne du chêne. Moins d'arbres ont été infectés par la maladie lorsque les coupes ont été recouvertes d'un produit, mais les différences parmi les taux d'infection des coupes d'élagage n'étaient pas statistiquement significatives. Les diamètres des arbres et le ratio de défilement de la tige n'avaient aucun impact significatif sur les taux d'infection. La méthode Shigo est reconnue comme étant supérieure pour l'élagage, mais il n'y a pas de raison de modifier les recommandations courantes qui sont d'appliquer un produit de recouvrement sur les blessures fraîches sur les chênes dans les secteurs hautement susceptibles à la flétrissure verticiléenne du chêne.

Zusammenfassung. Der Erreger Ceratocystis fagacearum verursacht die zerstörerische Krankheit, die Eichenwelke genannt wird. Eine Art der Verbreitung ist die durch Insekten (Nitidulidae), welche die Sporen in frische Wunden an gesunden Bäumen übertragen. In Zentral-Texas wurden Untersuchungen an Quercus fusiformis durchgeführt, um Schnittmethoden und Wundverschlussmittel und ihr Einfluss auf die Krankheitsentwicklung zu testen. Drei Behandlungskombinationen wurden an 30 Bäumen (10 Bäume/ Behandlung) getestet: glatter (stammparalleler) Schnitt unbehandelt, glatter (stammparalleler) Schnitt behandelt und unbehandelte glatte Schnitte nach der Shigo-Methode (Astkragen). Unbehandelte Punktwunden wurden im unteren Stammbereich von 20 weiteren Bäumen zur Kontrolle angebracht. Die Sporen von Ceratocystis fagacearum wurden auf die Schnittwunden und die Hälfte der Punktwunden (positive Kontrolle) aufgebracht, während die andere Hälfte der Punktwunden mit destilliertem Wasser als negative Kontrolle behandelt wurde. Die Symptome der Eichenwelke erschienen als erstes 31 Tage nach der Behandlung auf den unbehandelten stammparal- lelen Schnittwunden. Die Infektionsraten waren (in abnehmender Reihenfolge): positive Kontrolle 70\%, glatter Schnitt unbehandelt $60 \%$, Shigo-Methode $40 \%$ glatter Schnitt behandelt $20 \%$ und negative Kontrolle $10 \%$. Astungswunden, unabhängig von der Methode, sind effektive Infektionsherde für den Eichenwelken-Erreger. Bei behandelten Wunden wurden weniger Bäume infiziert, aber die Unterschiede zwischen den Infektionsraten bei beschnittenen Bäumen waren statistisch nicht relevant. Baumdurchmesser und Stammaspekt-Verhältnis hatten keinen Einfluss auf die Infektionsraten. Die Shigo-Methode wird als eine bevorzugte Methode für Baumschnitt angesehen, aber es gibt keinen Grund, gegenwärtige Empfehlungen zum Behandeln von frischen Wunden an anfälligen Eichen in Gegenden mit Eichenwelken-Befallsdruck zu ändern.

Resumen. Ceratocystis fagacearum causa la enfermedad destructiva llamada marchitamiento del encino. Un medio de dispersión del patógeno es por insectos vectores (Nitidulidae) que transmiten las esporas a las heridas frescas en árboles saludables. Los experimentos fueron conducidos en Texas central en encinos nativos (Quercus fusiformis) para probar los métodos de poda y pinturas en el desarrollo de la enfermedad. Se probaron tres combinaciones de tratamientos en 30 árboles (10 árboles/tratamiento): corta a ras sin pintar, corta a ras pintada, y corta sin pintar hecha de acuerdo al método de Shigo. Como control se hicieron heridas mediante perforaciones en las partes bajas de los troncos en 20 árboles adicionales. Las esporas de Ceratocystis fagacearum fueron aplicadas a las cortas de las podas y la mitad de los controles (controles positivos), mientras que la otra mitad de los controles recibió agua destilada como controles negativos. Los síntomas del marchitamiento del encino aparecieron primero en los tratamientos cortados a ras sin pintura, 31 días después de la inoculación. Las tasas de infección, en orden decreciente, fueron: control positivo (70\%), corta a ras sin pintar $(60 \%)$, método de poda de Shigo (40\%), corta a ras pintada (20\%), y control negativo (10\%). Las heridas de la poda, sin importar el método, fueron efectivas para la infección del patógeno del marchitamiento del encino. Pocos árboles resultaron infectados cuando las heridas fueron pintadas, pero las diferencias entre las tasas de infección para las cortas de la poda no fueron estadísticamente significativas. La relación de los diámetros de los árboles y el tronco no tuvo relación con las tasas de infestación. El método Shigo es reconocido como un método superior para la poda, pero no hay razón para cambiar las recomendaciones actuales de pintar las heridas frescas en encinos susceptibles en áreas de alto riesgo de marchitamiento del encino. 